\title{
ПЕРСПЕКТИВИ РОЗВИТКУ ЕКОНОМІКИ СПІЛЬНОГО СПОЖИВАННЯ В УКРАЇНІ
}

Анотація. Сьогоднішній розвиток вітчизняної економіки тісно зв’язано з використанням цифрових технологій у всіх її галузях. Стрімкому зростанню даного процесу сприяв карантин 2020 року. Корона вірус прискорив цифровізацію всіх процесів. Такі поняття як віддалена робота, дистанційне навчання, телемедицина стали буденними без особливого вибору, а сама ситуація, що склалася фундаментально змінила напрямки і швидкість розвитку економік світу. Якщо дивитися в бік стрімкого розвитку економіки спільного споживання, то при всіх зручностях і перевагах використання цифрових технологій сучасні продукти бізнесів, що працюють на нашому ринку оренди девайсів, залишаються не всім доступними за своєю вартістю. На заході широко поширений наступний термін DaaS (Device as a Service) або «девайс як послуга». Маеться на увазі, що по суті, споживач купуе не саму річ, а тільки її функціонал. Сьогодні населення великих міст успішно використовує продуктами систем підписок в сфері послуг (мобільні додатки, онлайн-кінотеатри і т.п.), зараз ця тенденція стрімко поширюеться на фрізичні товари.

Ключові слова: шеринг-економіка, оренда, економіка спільного споживання, поведінкова психологія, сервіс за підпискою, стартап.

Mavrina Maryna

Priazovsky State Technical University

\section{PROSPECTS OF DEVELOPMENT OF SHARING ECONOMY IN UKRAINE}

Summary. Today, the development of Ukraine's economy depends on the use of digital technologies in all its industries. Quarantine in 2020 contributed to the rapid growth of this process. Corona virus has accelerated the digitization of all processes. Such concepts as remote work, distance learning, telemedicine have become commonplace without much choice, and the situation itself has fundamentally changed the direction and speed of development of world economies. If we look at the rapid development of the economy of shared consumption, then with all the conveniences and benefits of using digital technologies, modern business products operating in our market of device rental, are not available to everyone at their cost. In the West, the following term "device as a service" is widely used. It means that, in fact, the consumer buys not the thing itself, but only its functionality. Today, the population of large cities successfully uses the products of subscription systems in the service sector (mobile applications, online cinemas, etc.) now this trend is rapidly spreading to physical goods. New socio-economic model of shared consumption, which in essence is an IT-reincarnation of the model of collective economy in a market paradigm. Sharing is closely related, to the concepts of conscious consumption and Zero Waste, and fully meets the needs of the younger generation, which increasingly refuses to buy, preferring Sharing. The most promising segment of the national Sharing economy is the exchange or rental of physical things. The technological solution of the subscription system is very promising, because in it the business processes are built in such a way that the organization can provide its services hundreds of times cheaper than competitors and at the same time have a very large coverage area. However, sharing services operating in the Ukrainian market still have high tariffs. If a new technological solution, is introduced, at the municipal level, which is based on the use of a long-term subscription system, alternative public transport can be obtained. The new transport will provide many advantages, namely they can be used in quarantine conditions, will reduce the number of vehicles during rush hour, solve the problem of parking vehicles and attract significant funds to local budgets.

Keywords: sharing economy, rent, behavioral psychology, subscription service, start up.

Постановка проблеми. 3 огляду на тепе1 рішній стан економіки України, для успішного фуннкціонування вітчизняних комерційних підприемств необхідною е не тільки оріентація на найбільш повне задоволення актуальних споживчих потреб, але й своєчасне виявлення цих потреб. Це пов'язано з низькою факторів.

По-перше, дуже швидко змінюються споживчі тренди, змінюеться культура і особливості споживання. Люди все більше замовляють послуги за підпискою. Економлять на всьому, при цьому вони хочуть продукт високої якості в супроводі хорошого сервісу.

По-друге, сучасні інформаційні технології, які розвиваються галопуючими темпами, змінюють докорінно майже всі ринки, особливо продовольчий ринок і громадського харчування. На них сильно тиснуть нові агрегатори доставки готової їжі, які вже намагаються диктувати меню і ціни.
По-трете, великі конкуренти заходять в непрофільні для себе види економічної діяльності, і при наявності великого капіталу в поеднанні з технологіями виснажують, а то і на завжди виводять 3 гри старих гравців на ринку $[1$, с. 1$]$.

По-четверте, глобальні кризи призводять до постійно зростання нерівності доходів. I як наслідок, більшості населення доводиться ретельно контролювати свої витрати. Люди вже не готові купувати дорогі речі, якими ніколи не користувалися і не до кінця впевнені в заявлених виробником характеристиках. При цьому оренда дає можливість зрозуміти на скільки той чи інший продукт може підійти споживачеві.

Все це створило сприятливі умови для стрімкого розвитку моделі економіки спільного споживання (Sharing economy) в основу, якої покладено ідею зручності користування, а не володіння і накопичення [2, с. 60]. 
Аналіз останніх досліджень i публікацій. Питанням сутності та розвитку шерінгової економіки присвячені роботи наступних вчених: Б. Волш, Ф. Маззелла, М. Спенс, Д. Прабху, Г. Левіс та ін. Рейчел Ботсман та Ру Роджерс у 2010 рощі, в книзі «What's Mine Is Yours: Rise Of Collaborative Consumption» [3] дуже детально сформували та описали конщепщію економіки спільно споживання. $\mathrm{Pa}$ зом з тим, аналіз наукових публікацій показуе, що сама конщепція спільного поживання заснована на наступних принщипах: ращіональне споживання фізичних благ та послуг, ефективне використання часу, зріст соціального рівня довіри, використання цифррових технологій. Комуністичне гасло «від кожного за здібностями, кожному за потребами» несподівано вистрілило в новій соціо-економічній моделі спільного споживання. Тобто, не потрібно купувати автомобілі, квартири, яхти, девайси і багато іншого, якщо всім цим можна користуватися, не витрачаючи ресурси на утримання і ремонт. I при цьому все це можна змінювати стільки разів, скільки захочеться або скільки зможеш фінансово.

Виділення невирішених раніше частин загальної проблеми. Однак, в нашій країні існуе одна істотна проблема в даному секторі економіки, а саме високі тарифи шеринг сервісів. Немае альтернативи використання дорогих сучасних фізичних товарів, не купуючи їх або не беручи в оренду у шерингових компаній, тому що в обох варіантів е свої недоліки. 3 одного боку, проблема з якою стикаються споживачі - це вибір моделі, а саме не розуміння що підходить саме їм. Адже діапазон цін, наприклад, на електросамокати коливаеться від 6 до 36 тис. грн. Не кожен готовий відразу віддати подібну суму без розуміння яка модель підходить саме йому. Сучасному споживачу дуже важлива функціональність, і відсутність досвіду використання стае істотною перешкодою для здійснення покупки. С другої сторони, більшість прокатників працюють за моделлю free-float: взяти й залишити самокат можна в будь-якому місці в межах окреслених зон. То б то самокати треба щодня забирати, заряджати, лагодити, охороняти. Все це суттево збільшуе вартість шеринга.

Метою статті $е$ визначення напрямів розвитку економіки спільного споживання в Україні на основі отриманих даних при вирішенні наступних завдань:

- розглянути переваги шеринг економіки і перспективи її розвитку в нашій країні;

- визначити основні напрямки діяльності українських шеринг платформ;

- проаналізувати успішний досвід зарубіжних шеринг компаній з метою його застосування в Україні;

- виявити напрямки та перспективи розвитку економіки спільного споживання в Україні з урахуванням використання позитивного досвіду зарубіжних країн.

Виклад основного матеріалу. До переваг, які дає економіка спільного споживання, відносяться: гнучкість, незалежність, раціональне споживання (друге життя речей, оренда, спільне використання), зміцнення соціальної довіри, економічні вигоди. Але існують певні недоліки: безпека, пробіли в законодавстві, проблеми швидкого росту, нестабільність.
Перспективи глобальної шеринг економіки в цифррах:

- \$335 млрд досягне до 2025 року обсяг світової шеринг економіки. У 2014 році глобальний ринок шеринга оцінювався в $\$ 15$ млрд.

- \$23 млрд венчурних інвестицій привернула за останні десять років шерінг економіка.

- $45 \%$ усіх існуючих в даний час шерингових сервісів були створені в США.

- 43\% населення США схильні вважати, що володіння чим-небудь $е$ проблемою, оскільки вибір вимагае часу, а вартість активу бувае високою і не виправдовуе покупки, якщо в ній немає постійної необхідності [4].

Україна їде в напрямку глобальних тенденцій в сфері економіки спільного користування. У вітчизняній ніші прижилися і з успіхом працюють відділення таких міжнародних платформ, як сервіс короткострокової оренди Airbnb, сервіс 3 пошуку попутників BlaBlaCar, сервіс німецької компанії nextbike, Uber. Але треба відзначити і українські сервіси. RENT A BRAND - сервіс оренди нарядів, працюе з грудня 2012 року [5]. TravelPost - платформа для попутної доставки багажів та різного роду приватних вантажів, запущена у травні 2018 року. Сервіс доступний через мобільні додатки [6]. Kabanchik.ua - онлайн cepвіс пошуку приватних фахівців для вирішення побутових і бізнес задач. Майданчик був запущений у вересні 2012 року двома молодими підприемцями Романом Кірігетовим і Олександром Юр'євим. В даний час сервіс працюе у всіх великих містах України, а також в Білорусі і Казахстані [7].

На сьогоднішній день великою популярністю користуються шеринг сер-виси електросамокатів. За даними журналу Forbes в Україні на сьогодні працюе 6 таких. Це пов'язано з наступними причинами: активне працездатне населення втомилось від нескінченних пробок і пошуку вільних паркувальних майданчиків. Тому вони відмовляються від автомобіля на користь електросамоката. Це суттево економить час, майже вдвічі швидше, ніж у годину пік на автомобілі. Кожна поїздка на прокатному самокаті середньому коштуе 70 грн в одну сторону. Такі молоді активні городяни, основна цільова аудиторія шеринг сервісів. Карантин зробив свої корективи, та кількість користувачів за 2020 рік зросла в десятки тисяч разів, хоча досі це досить витратно для споживачів.

За даними міжнародної консалтингової компанії McKinsey було складено прогноз, який виявив, що обсяг ринку шеринг сервісів мобільних девайсів до 2030 року покаже значний зріст, а саме у $\$ 200-300$ млрд у США, та $\$ 100-150$ млрд у Європі. Тому що, через ризик зараження більшість населення уникають місця громадського скупчення людей.

Слід відзначити компанії, які у 2020-2021 роках зайшли на український ринок: Bolt, Kiwi, Scroll, Bikenow, Zelectra i Vzhooh. За оцінками девелоперів Kiwi український ринок прокату все ще $є$ відкритим та не заповненим [8].

Нескладно помітити, що успішний шеринг в сучасному світі не можливий в оф-лайн форматі. Тобто він набирає обертів за умови використання інтернет ресурсу, а саме власного сайту компанії, інтернет реклами і додатків для смртфонів. Розвиток шеринг економіки тісно пов'язано з поширенням інтернет ресурсів. Відомий вислів амери- 
канського підприємця, мільярдера Білла Гейтса: «Якщо вашого бізнесу немає в інтернеті, значить, вас немае в бізнесі» [9]дуже точно описуе суть економіки спільного споживання.

При аналізі сайтів успішних шеринг сервісів нашої країни, або зарубіжних було виявлено, що всі вони були створені 3 урахуванням маркетингової формули AIDA. Тобто едективне використання поведінкової психології в структурі сайтів, а саме: захоплюють увагу, викликають інтерес і бажання, як підсумок - підштовхують до здійснення покупки.

Розглянемо приклад вдалого технологічного рішення компанії «Мій самокат» (Росія), девелопери якої прийшли до рішення довгостроковій підписки і надання високого рівня сервісу за бюджетні кошти. Так наприклад година користування самокатом у перерахунку на національну валюту коштуе від 1,75 грн, що в сотню разів дешевше сервісів, які працюють на українському ринку.

Ідея заснована на тому, що за системою підписки споживач може для себе визначити на скільки йому підходить та чи інша модель девайса не витрачаючи при цьому значні кошти i отримуючи при цьому повне технічне обслуговування без застави. Крім того, для самого сервісу з'являеться можливість працювати в секторі В2В (бізнес до бізнесу). У порівняння з електросамокатами, які пропонують в оренду, система підписки виявляеться в рази дешевше, плюс за час користування можна міняти на будь-які інші гаджети, які є у компанії [10].

Сучасні умови оренди самокатів - це не зовсім оптимальний варіант для тих, хто хоче використовувати даний вид транспорту кожен день, тому що шеринг в нашій країні - це досі для більшості населення витратно. Тарифи зараз приблизно такі ж, як і на каршерінг (2 грн/хв). Тому варіант довгострокової оренди або оренда за підпискою - це вигідний варіант, де можна за невелику суму отримати в користування електросамокат або інший подібний девайс і до того ж повне обслуговування протягом всього терміну оренди. Порівняння підписки, оренди та купівлі приведено в таблиці 1 [11].
Підписка на девайси була запущена в квітні 2020 року і вже через пару місяців вийшла в операційний прибуток. Попит був не тільки в сегменті В2С (бізнес для споживача), але і буквально за місящ з'явився з боку кур'єрів і В2В-сегмента.

Рішення виявилося на стільки унікальні, що підійшло досить широкої аудиторії споживачів: для тих, хто хоче щоденно і вигідно використовувати девайс, для тих, хто сумніваеться в покупці особистого девайсу, або тих, хто точно хоче купити, але боїться, що девайс зламається і доведеться витрачати додатковий час і гроші на лагодження [10]. Порівняння вартості зарубіжної підписки (перераховано за курсом НБУ) і оренди самокатів в Україні наведено в таблиці 2 .

За даними наведеними у таблищі 2, можна зробити наступний висновок: технологічне рішення системи підписки дуже перспективне, адже в ній бізнес процеси побудовані таким чином, що організація може надавати свої послуги в сотні разів дешевше ніж у конкурентів та при цьому мати дуже велику зону покриття. Якщо запровадити подібну програму у великих містах України на муніџипальному рівні, то можна одночасно вирішити декілька завдань: знизити навантаження доріг у час пік, знизити рівень загазованості повітря та отримати додаткові кошти до місцевих бюджетів.

Висновки 3 даного дослідження i перспективи. Підводячи підсумки, можна дійти такого висновку, на початку XXI століття в умовах капіталізму виросла нова соціо-економічна модель спільного споживання, яка за своєю суттю є IT-реінкарнацією моделі колективного господарства в умовах ринкової парадигми. Економіка спільного споживання (Sharing economy) тісно пов'язана 3 концепціями усвідомленого споживання и Zero Waste, і повністю задовольняє потреби молодого покоління, яке все частіше відмовляеться від покупок, віддаючи перевагу Sharing сервісам. Найбільш перспективним сегментом національної Sharing economy є обмін або прокат фрізичних речей. Але шеринг сервіси, які працюють на ринку України все ще мають високі

Коротке порівняння підписки, оренди та купівлі

Таблиця 1

\begin{tabular}{|c|c|c|c|}
\hline & Сервіс за підпискою & Покупка & Оренда \\
\hline Вартість & від 1102 грн & від 10000 грн & від 2000 \\
\hline Застава & 0 грн & 0 грн & від 3000 \\
\hline Стан девайсу & $\bullet \bullet \bullet \bullet$ & $\bullet \bullet \bullet \bullet$ & $\bullet$ \\
\hline Повернення & $\begin{array}{c}\text { В кінці місяця, якщо не потрібен } \\
\text { або можна продовжити користування }\end{array}$ & $\begin{array}{c}\text { Повернення можливе } \\
\text { тільки в обмежених } \\
\text { випадках }\end{array}$ & $\begin{array}{c}\text { Необхідно повернути } \\
\text { в кінці терміну оренди }\end{array}$ \\
\hline $\begin{array}{c}\text { Технічне } \\
\text { обслуговування }\end{array}$ & $\begin{array}{c}\text { Оперативна заміна комплектуючих } \\
\text { у випадку поломки }\end{array}$ & $\begin{array}{c}\text { Тільки гарантійний } \\
\text { ремонт від 30 днів }\end{array}$ & $\begin{array}{c}\text { Ризик не повернути } \\
\text { заставу в разі поломки }\end{array}$ \\
\hline
\end{tabular}

Джерело: [11]

Таблиця 2

Порівняння вартості зарубіжної підписки на девайс та сервісів оренди самокатів в Україні

\begin{tabular}{|c|c|c|c|c|}
\hline $\begin{array}{c}\text { № } \\
\text { з/п }\end{array}$ & Показники/Сервіси & Зарубіжна підписка на девайс & «Вolt» & «Kiwi» \\
\hline 1 & Ціна, грн/година & від 1,75 & від 203 & 165 \\
\hline 2 & Зона покриття & Вся територія міста & Тільки центр міста & Тільки центр міста \\
\hline 3 & Умови використання & Договір між сервісом та споживачем & Достатньо додатку & Достатньо додатку \\
\hline
\end{tabular}

Джерело: розроблено автором за даними [11; 12] 
тарифри. Якщо запровадити на муніципальному рівні нове технологічне рішення, яке побудоване на основі використання системи довгострокової підписки, то можна отримати альтернативний громадський транспорт. Новий транспорт буде надавати безліч переваг, а саме їм можна буде користуватися в умовах карантину, дозволить знизити кількість транспорту в години пік, вирішити проблему паркування автотранспорту та залучити значні кошти до місцевих бюджетів.

\section{Список літератури:}

1. Мавріна М.I. Моделювання процесів рефлексивного управління споживчим попитом комерційних підприємств : автореф. дис. канд. екон. наук : 08.00.11. Запоріжжя, 2020. 20 c.

2. Мавріна М. Економіка спільного споживання в Україні. Зовнішні та внутрішні ббактори впливу на обормування еконолічної систели : збір. тез наук. робіт Всеукр. наук.-практ. конф. (Одеса, 8 травня 2021 р.). Одеса, 2021. С. 60-62.

3. Botsman R., Rogers R. What's Mine Is Yours: The Rise of Collaborative Consumption. London : Harper Business, 2010. $280 \mathrm{p}$.

4. Макаренко Г. Экономика шеринга в 30 цифрах и фрактах. Инфорлационное агентство РБК. URL: https://trends.rbc.ru/trends/sharing/5ddbb3279a7947b01be74c19 (дата звернення: 18.05.2021).

5. Офіційний сайт сервісу оренди дизайнерських суконь «RENT A BRAND». URL: https://rentabrand.ua/about-us/ (дата звернення: 18.05.2021).

6. Офіційний сайт сервісу доставки посилок мандрівниками «TravelPost». URL: https://travelpost.io/uk/about/ (дата звернення: 18.05.2021).

7. Офріщійний сайт сервісу пошуку фрахівців для побутових і бізнес задач «Kabanchik.ua». URL: https://kabanchik.ua/ about (дата звернення: 18.05.2021).

8. Іванова К. В Україні працюе шість сервісів шерингу електросамокатів. Пояснюємо на цифрах, як влаштований цей ринок. Украӥнська інтернет версія журналу Forbes. URL: https://forbes.ua/innovations/vukraini-pratsyue-pyat-servisiv-sheringu-elektrosamokativ-poyasnyuemo-na-tsifrakh-yak-vlashtovaniy-tseyrinok-16062021-1844 (дата звернення: 18.06.2021).

9. Офіційний сайт «Quotes of famous people». URL: https://ru.citaty.net/tsitaty/656030-bill-geits-esli-vashegobiznesa-net-v-internete-to-vas-net-v/?page=11 (дата звернення: 15.06.2021).

10. Почему будущее за подпиской на товары? Фаундеры сервиса «Мой самокат» делятся опытом развития стартапа. Платборла для предпринилателей «vс.ru». URL: https://vc.ru/life/178212-pochemu-budushchee-za-podpiskoy-natovary-faundery-servisa-moy-samokat-delyatsya-opytom-razvitiya-startapa (дата звернення: 15.06.2021).

11. Офіційний сайт сервісу оренди девайсів за підпискою «Мой девайс». URL: https://www.moydevice.ru (дата звернення: 15.06.2021).

12. Bolt і Kiwi: порівняння сервісів прокату електросамокатів в Києві. Украӥнське онлайн-видання «Украӥнський спектр". URL: https://uaspectr.com/2020/09/16/bolt-i-kiwi-porivnyannya-servisiv-prokatu-elektrosamokativ-vkyyevi (дата звернення: 15.06.2021).

\section{References:}

1. Mavrina M.I. (2020) Modeliuvannia protsesiv refleksyvnoho upravlinnia spozhyvchym popytom komertsiinykh pidpryiems [Modeling the processes of reflexive management of consumer demand of commercial enterprises]. (PhD Thesis), Zaporizhzhia: Classical Private University.

2. Mavrina M.I. (2021) Ekonomika spilnoho spozhyvannia v Ukraini [Schering economy in Ukraine]. External and internal factors influencing the formation of the economic system: collection of abstracts, (Ukraine, Odessa, May 8 , 2021), Odessa: Center for Economic Research and Development, pp. 60-62.

3. Botsman R., Rogers R. (2021) What's Mine Is Yours: The Rise of Collaborative Consumption. London: Harper Business, $280 \mathrm{p}$.

4. Makarenko G. (2020) Ekonomika sheringa v 30 czifrakh i faktakh [The economics of sharing in 30 digits and fact]. Informaczionnoe agentstvo RBK [RBC Information Agency]. Available at: https://trends.rbc.ru/trends/ sharing/5ddbb3279a7947b01be74c19 (accessed 18 May 2021).

5. Official website for the service of the rent of designer cloth «RENT A BRAND». Available at: https://rentabrand.ua/ about-us/ (accessed 18 May 2021).

6. Official site of the parcel delivery service for travelers «TravelPost». Available at: https://travelpost.io/uk/about/ (accessed 18 May 2021).

7. Official site of the service of finding specialists for household and business tasks "Kabanchik.ua». Available at: https://kabanchik.ua/about (accessed 18 May 2021).

8. Ivanova K. (2021) V Ukraini pratsiuie shist servisiv sherynhu elektrosamokativ. Poiasniuiemo na tsyfrakh, yak vlashtovanyi tsei rynok [There are six electric scooter sharing services in Ukraine. We explain in numbers how this market, is arranged]. Ukrainska internet versiia zhurnalu Forbes [Ukrainian online version of Forbes magazine]. Available at: https://forbes.ua/innovations/v-ukraini-pratsyue-pyat-servisiv-sheringu-elektrosamokativpoyasnyuemo-na-tsifrakh-yak-vlashtovaniy-tsey-rinok-16062021-1844 (accessed 18 June 2021).

9. Official site «Quotes of famous people». Available at: https://ru.citaty.net/tsitaty/656030-bill-geits-esli-vashegobiznesa-net-v-internete-to-vas-net-v/?page=11 (accessed 18 May 2021).

10. Platform for entrepreneurs "vc.ru» (2020) Pochemu budushhee za podpiskoj na tovary? Faundery servisa «Moj samokat» delyatsya opytom razvitiya startapa [Why is the future of product subscriptions? Founders of the "My Samokat" service share their experience in the development of a startup]. Available at: https://vc.ru/life/178212pochemu-budushchee-za-podpiskoy-na-tovary-faundery-servisa-moy-samokat-delyatsya-opytom-razvitiya-startapa (accessed 15 June 2021).

11. Official site of the device rental service with a subscription «My device». Available at: https://www.moydevice.ru (accessed 15 June 2021).

12. Ukrainian online publication «Ukrainian Spectrum» (2020) Bolt i Kiwi: porivniannia servisiv prokatu elektrosamokativ v Kyievi [Bolt and Kiwi: comparison of electric scooter rental services in Kyiv]. Available at: https://uaspectr.com/2020/09/16/bolt-i-kiwi-porivnyannya-servisiv-prokatu-elektrosamokativ-v-kyyevi (accessed 15 June 2021). 